Journal of Educational Method and Technology Vol. 2 No. 3, Desember 2019

P-ISSN 2622-8459 E-ISSN 2622-8467

http://ejournal.unima.ac.id/index.php/jemtec

\title{
The Effect Of Students' Japanese Vocabulary On Their Comprehension Of Japanese Text
}

\author{
O Soidi ${ }^{1}$ \\ ${ }^{1}$ Universitas Negeri Manado, Indonesia \\ corresponding author: ${ }^{1}$ orestissoidi@unima.ac.id
}

\begin{abstract}
The aim of the study is to find out the impact of students' mastery of Japanese vocabulary on their comprehension of Japanese text. The respondents were the students of Japanese Language Education Study Program at Manado State University. The study is an ex-post facto research. Data collection used vocabulary tests and reading comprehension tests. Data analysis was performed by correlation analysis with the coefficient of determination and simple regression analysis. The study results show that there is a positive and significant relationship between vocabulary mastery and reading comprehension skills of students of Japanese Language Education Study Program at Manado State University with a correlation coefficient of $0.613, \mathrm{R} 2$ of 0.375 , adjusted $\mathrm{R}$ of 0.373 with $\mathrm{p}<0.05$, and correlation coefficient partially 0,151 .
\end{abstract}

\section{Introduction}

\section{Background of the Study}

Japanese language instruction deals with four language skills, namely listening skill, speaking skill, reading skill and writing skill. These four skills are very closely related to each other. For Japanese language learners, language skills are strongly influenced by the mastery of writing, vocabulary and language structure. Therefore, students of Japanese language need to master the vocabulary and structure of Japanese language in order to communicate well and fluently, or to be able to read and comprehend Japanese text.

The connection between the mastery of language elements such as vocabulary and structure with language skills is unquestionable. A person cannot speak in any given language if he has no knowledge of the language's vocabulary and structure. If someone masters grammar but does not master the vocabulary of a language, he will not be able to communicate in that language. Similarly, if someone masters the vocabulary of a language but has no knowledge of the grammar, his speech is very likely to be incomprehensible. He will not be able to understand the speech of others or to understand any text of the language as well.

Although it has been realized that there is a connection between the mastery of a language's elements and language skills, it is not clear yet how much the effect the former has on the language skills. This study objective is to analyze the effect of the mastery of Japanese vocabulary on Japanese reading comprehension skill. 
In Japanese Language Study Program curriculum, the objective of reading comprehension subject (dokkai) is to build and to develop students reading comprehension skill of Japanese texts. In my experience of teaching reading comprehension subject, there are three factors that hinder students' ability to develop their comprehension skill of Japanese texts. These factors are mastery of Japanese vocabulary, mastery of kanji and mastery of Japanese grammar. Regarding mastery of Japanese grammar, it can also be stated that apparently students have difficulty in applying their knowledge of Japanese grammar (bunpo) into the process of understanding Japanese text.

Based on the above facts and reasons this study aims to examine the effect of mastery of Japanese vocabulary on the understanding of Japanese reading texts by students of the Japanese Language Study Program at Manado State University.

\section{Research Question}

How does the mastery of Japanese vocabulary affect the understanding of Japanese texts by students of the Japanese Language Study Program at the Faculty of Language and Art, Manado State University?

\section{Basic Assumptions}

1) Mastery of the elements of language contributes to language skills.

2) The ability to understand Japanese texts is inseparable from the mastery of Japanese vocabulary.

3) In the teaching process at the Japanese Language Education Study Program of Manado State University, students learn Japanese vocabulary both in special subjects and in other subjects dealing with other elements of Japanese language.

\section{Research Objectives}

The purpose of this study was to determine how much the contribution of students' Japanese vocabulary to their comprehension of Japanese text.

\section{Research Benefits}

The results of this study are expected to

1) be used as a source for consideration for the manager of the Japanese Language Study Program of Manado State University in designing and developing Japanese language education curricula.

2) Provide encouragement for lecturers of the Japanese Language Education Study Program of Manado State University to study and develop methods and media for teaching Japanese vocabulary.

\section{Literature Review \\ Vocabulary}

Any language skill cannot be separated from the mastery of vocabulary, because the core of a language is the word. Vocabulary refers to the richness of words in a particular language. Linguists have proposed many definitions of vocabulary. Soedjito (in Tarigan, 2008) suggests that vocabulary can be interpreted as: (1) all words in a language; (2) all words a speaker or writer knows; (3) words 
used in a field of science; and (4) a list of words arranged like a dictionary accompanied by a brief and practical explanation.

A person's vocabulary is the collection of words in his/her memory. He/she will immediately recognize any word of that collection when he heard or read it. The recognition manifests in the form of understanding the meaning or in actions demanded by the word. There are words that cause reactions faster, some are slower according to the level of intimacy of the vocabulary (Keraf, 2007).

Djiwandono (2011) argues that vocabulary is a group of words in various forms which include: loose words with or without affixes, and words that are a combination of the same or different words, each with their meanings own.

Meanwhile according to Chaer (2011) Indonesian vocabulary is all the words contained in Indonesian. The first source of Indonesian vocabulary comes from Malay, then added from the vocabulary of several regional languages, and enriched with foreign language vocabulary (Arabic, Dutch, English, etc.).

Nurgiyantoro (2014) explained that vocabulary is a collection of words of a speaker, writer, or a language. Vocabulary is also a component of language that contains all the information about the meaning and usage of words in the language.

Based on the above mentioned definition of vocabulary, it can be said that the vocabulary is a collection of words that someone uses in language activities. A speaker must have a mastery over the vocabulary of a language in order to express their thoughts and feelings in various spheres of life in a certain give language, or to be able to understant other's speech.

Tarigan (2015) argues that the quality of a person's language skills depends on the quantity and quality of their vocabulary. The richer the vocabulary we have, the more likely we are skilled at language. Therefore vocabulary teaching in elementary schools must be the basis for developing students' language skills.

\section{Text or Discourse}

Discourse is (1) words, speeches, speech which form a single unit, and (2) the whole speech. Discourse is a structured event realized in linguistic behavior (text), and the text is a sequence of linguistic expressions structured to form a unified whole (Fatimah, 1994). A text is not merely a random sequence of related sentences. In a text, sentences are placed in neat order and there are formal means which mark the true nature of the relationships intertwined between sentence sequences. The tools used are lexical and grammatical tools (Tarigan, 2008).

\section{The Nature of Reading}

Reading is the key to learning, because reading is the most complete and modern learning resource, inexpensive, easy, and the fastest to obtain. By reading we can learn many things at once. Furthermore, reading can make people wiser, because by reading people broaden the horizons of their lives, freed from their narrow closed and limited world both in terms of time and space (Widyamartaya, 2000).

Human are not only required to understand oral presentations but are also required to be able to read and understand written language. Kamus Besar Bahasa Indonesia defines reading as (1) seeing and understanding the contents or meaning of written text; (2) spelling or pronouncing written words; (3) saying; (4) knowing, predicting; (5) predicting, calculating, understanding. (Balai Pustaka, 1990) 
Journal of Educational Method and Technology Vol. 2 No. 3, Desember 2019

P-ISSN 2622-8459 E-ISSN 2622-8467

http://ejournal.unima.ac.id/index.php/jemtec

There are four levels of reading according to Mortimer J. Adler in Widyamartaya (2000) namely basic reading, review reading, careful reading, and comparison reading. (1) Basic reading, is reading taught at the elementary school focusing on language use. (2) Review reading is reading to understand as much as possible within an allocated time. (3) Careful reading is reading to truly understand a book. (4) Comparison reading is reading a number of books of the same field to find out solution of a certain problem.

\section{Reading Comprehension}

\section{Understanding Reading Comprehension}

Reading comprehension (reading for understanding) is a type of reading that aims to understand (1) literary standards; (2) critical review; (3) printed drama; (4) paterns of fiction (Tarigan, 2008). According to Rubin (in Somadayo, 2011) reading comprehension is a complex intellectual process that includes two main abilities, namely understanding of words' meaning and the ability to think about verbal concepts. In reading comprehension there is a two-way concentration in the reader's mind namely, the reader actively responds to text by expressing the sound of the text and language used by the author. Therefore, reader has to be able to express the meaning of a text.

Dalman (2014) states that reading comprehension is a high level reading skill. Reading comprehension is cognitive reading (reading to understand). Meanwhile, according to Somadayo (2011) understanding of text occurs through a matching process or interaction between knowledge in the reader schemata with concepts / understandings / facts contained in the text. Thus, understanding of a reading material does not only depend on what is contained in the reading alone, but also depends on the knowledge that has been read by the previous reader. With this process the reader actively builds his understanding.

Based on the description above, it can be concluded that reading comprehension is a reading activity that requires the reader to know and remember the main points, as well as to know important things and its details. In reading comprehension also requires the reader's memory to comprehend the reading content in depth and use it well.

\section{Purpose of Reading Comprehension}

Somadayo (2011) suggests the main purpose of reading comprehension is to gain understanding. Someone is said to understand text well if he has the following abilities, (a) the ability to capture the meaning of words and expressions used by the writer; (b) the ability to capture explicit and implied meanings; and (c) the ability to make conclusions. A reader who already has a high level of reading ability has all aspects of reading ability. However, his level of understanding is of course limited.

In addition, Anderson (in Somadayo, 2011) states that reading comprehension has the aim to understand the content of text. These objectives include, (a) read to get details and facts; (b) read to get the main idea; (c) read to get the order of text organization; (d) read to get conclusions; (e) read to get a classification; (f) read to make a comparison or mid.

Meanwhile, Tarigan (in Somadayo, 2011) revealed the main purpose of reading comprehension is to seek answers to questions provided by readers based on 
the text. For this reason, these questions are: 1) why a title or topic chosed; 2) what problems are discussed in the text; and 3) what things the character learned and did.

Based on the explanation above, it can be concluded that the purpose of reading comprehension is to comprehend a text as a whole which includes the ability to find the main ideas, be able to capture implied or explicit meanings, obtain facts from a reading, determine the topic or title and can make conclusions from the contents.

\section{Principles of Reading Comprehension}

According to McLaugughlin \& Allen (Rahim, 2008) reading principles that influence reading comprehension are:

1) understanding is a social constructivist process;

2) literacy balance is a curriculum framework that fosters understanding;

3) professional (superior) reading teachers influence student learning;

4) good readers play a strategic role and play an active role in the reading process;

5) reading should occur in meaningful contexts;

6) students find the benefits of reading from various texts at various grade levels;

7) vocabulary development and learning affect reading comprehension;

8) participation is a key factor in the understanding process;

9) reading strategies and skills can be taught;

10) dynamic assessment informs reading comprehension learning.

While Brown (in Somadayo, 2011) states that the main principle of a good reader is the reader who actively participates in the reading process. They have clear objectives and monitor their reading goals from the texts they read. A good reader uses understanding strategies to make it easier to build meaning. This strategy includes reviewing, making one's own questions, making connections, visualizing, knowing words, forming meanings, monitoring, summarizing, and evaluating.

Based on the expert opinion above, it is concluded that the principle of reading comprehension is the reader should be able to integrate the information contained in the text with the knowledge he has. Readers try to relate what they read with their experiences.

\section{Stages of Learning Reading Comprehension}

In order for students to understand text, teachers should incorporate the stages of implementation in learning to read. Effective teachers should be able to direct students' minds on the topics to be studied. Roe \& Burns (2010) argues that teaching reading is based on the view of schemata theory. Based on the view of the schemata theory, reading is the process of forming meaning on the text. Therefore, teachers need to pay attention to the activities of pre-reading, reading, and post-reading.

a. Pre-reading

Burns (in Somadayo, 2011) argues that pre-reading activities are teaching activities that are carried out before students do reading activities. In pre-reading activities, the teacher directs attention to activating student schemata related to the reading topic. Activation of student schemata can be done in various ways, for 
example by preliminary review, anticipation guidelines, mapping of meaning, writing before reading, and creative drama.

Gruber (in Rahim, 2008) states that there are several techniques that can be done to activate student schemata through reading activities. The intended prereading activities are as follows:

1) the teacher reads the title of the reading, then introduces the students;

2) prediction activities to tell students' interests in reading by using a technique to predict pre-reading activities conducted by reading several pages aloud;

3) use various stimuli to maintain student attention on the lesson.

In this reading activity the teacher and students can carry out activities such as asking questions about the topic, then students answer these questions by connecting the background experience they have. That way students can generate schemata about topics so they can use their background knowledge and experience.

b. Reading

After the pre-reading stage, the next step is the reading stage. In this reading phase, strategies should be used to improve reading comprehension skills for students. Roe \& Burns (2010) suggests that the effective use of metacognitive strategies has a positive influence on understanding. Metacognitive strategies will affect student understanding.

Rubin (in Somadayo, 2011) argues that metacognitive itself refers to one's knowledge of intellectual functions that come from their own minds and their consciousness to monitor and control these functions. Metacognition involves analyzing current ways of thinking. In reading assignments, the reader who displays his metacognisis selects reading skills and techniques that are suitable for certain reading assignments.

In reading phase teacher should stimulate students' understanding abilities. Teacher can do activities such as reading stories and then asking students to listen to the stories he read. Then, he asks students about the contents of the text. In addition, he can also ask students to read their own stories. After that he asks students to tell what the contents of the story they have read.

c. Post-reading

The final stage in the reading activity is the post reading stage. Burns (in Rahim, 2008) suggests that post-reading activities are used to help students integrate the new information they read into the schemata they have in order to obtain a higher level of understanding. In this post-reading stage teacher can read the story or have students read the story in front of the class. Other students then discussed the settings, the character of the actors, and the story line. Then the teacher asks students to write about the message / moral of the story.

Further post-reading activities can be developed in the following ways: (1) students are given the opportunity to find further information about the topic; (2) students are given feedback with questions about the content of the answers; (3) students are given the opportunity to organize the material to be presented; and (4) students are given the opportunity to work on assignments to improve reading comprehension (Somadayo, 2011). 
Journal of Educational Method and Technology Vol. 2 No. 3, Desember 2019

P-ISSN 2622-8459 E-ISSN 2622-8467

http://ejournal.unima.ac.id/index.php/jemtec

\section{Reading Techniques}

In language teaching, in general oral language is taught first. Things like the sound system of a language, important and widely used grammatical patterns in spoken language, limited vocabulary, are taught at at the first stage of learning. After mastering spoken language, the amount of vocabulary will be increased gradually.

The reading material provided usually contains the language and vocabulary structure that students need to speak orally and the content is often adjusted to students' daily lives or their experience. If students have mastered enough spoken language and have been able to express themselves, then they start to learn to read. For the purpose of reading, it is necessary to develop the ability to read so that students realize that reading is also an essential language activity like speaking.

Experts say that the overall reading process is very complex because it involves the whole person of the reader, namely memory, experience, brain, knowledge, language skills, emotional and psychological states, and senses (eyes) as a means of seeing. According to Rooijakers (2003) there are several reading techniques, namely:

1) Read to get an impression of the contents and composition.

2) Read to get an impression of the most important things in each paragraph.

3) Read to search and formulate clearly about what you want to look for, looking at the contents of the reading carefully.

4) Read to learn, that is if someone wants to learn something in depth reading, which must be understood, remembered, used and applied.

\section{Reading Skills and Skills}

A good reader is someone who can perceive language (ideas, style and maturity of the author) and understand the reading at a normal pace. There are several skills needed to read with understanding, namely:

\section{Reading symbols and graphics}

Understand the vocabulary used in general (not specific) language and be able to deduce its meaning in its context. Understanding the syntactic forms and morphological features of the written language contained in the reading. Respond to graphic symbols of writing such as punctuation, capital letters. or paragraph used to clarify the meaning.

\section{Ideas}

Interpret the author's main intentions and opinions, and understand opinions that help the theme of the essay, and draw conclusions and valid responses from the material read.

\section{Tone and Style}

Get to know the author's attitude about the material and the reader, understand the tone and style of the language, and understand the patterns and elements of language used by the author in expressing his opinions. 
Journal of Educational Method and Technology Vol. 2 No. 3, Desember 2019

P-ISSN 2622-8459 E-ISSN 2622-8467

http://ejournal.unima.ac.id/index.php/jemtec

\section{Reading as a skill}

Reading is something that is very important for us. By reading someone can absorb the ideas of theory, analysis or discovery of others. Through reading activities, people can also develop themselves in their fields and can follow every development of science. This means that everyone, especially students, is required to be more active in reading to add and develop their knowledge through reading activities. According to Wiryodijoyo (1989) there are three kinds of reading skills, namely:

1) Word recognition skills

Basically this skill is in the form of:

a. Basic reading skills

b. Skills in reading influential words

c. Skills in reading compound words

d. Word group reading skills

2) Understanding skills

This skill is a skill to develop language skills.

3) Learning skills

Learning skills on 'reading' are known as functional skills of reading. Reading learning requires understanding, the ability to find and read maps, summaries, graphs, and use them according to the contents of the reading.

\section{Reading Comprehension Ability Test}

Nurgiyantoro (2014) argues that not unlike the listening competency test, the problem that arises in the reading competency test is how to measure the comprehension ability of the message. If a test simply requires students to identify, choose, or respond to the answers that have been provided, for example in the form of objective questions such as multiple choice, the test is a traditional test. Conversely, if the written message comprehension test at the same time requires students to construct their own answers, both verbally, in writing, and both, the test becomes authentic.

Both types of tests are needed to measure student learning outcomes. Multiple-choice questions are more effective when considering work time and time to correct answers. In addition, with the multiple choice questions the validity and reliability of the test is more likely to be fulfilled because the multiple-choice questions are able to accommodate many questions. This multiple-choice test measures students' reading comprehension ability by selecting the answers provided.

Questions with multiple choice objective forms can be made varying in degree of difficulty depending on the level of difficulty of the discourse and the complexity of the questions concerned. One way to find out students' reading comprehension skills is by conducting a reading comprehension test. This reading comprehension test aims to determine the level of cognitive ability of students in understanding a reading. The cognitive domain is usually related to aspects of students' knowledge and intellectual abilities in understanding a reading.

In this study, researchers measured students' reading comprehension skills by using multiple choice objective form questions. The form of reading is a short story with the theme of environment and transportation. 
Journal of Educational Method and Technology Vol. 2 No. 3, Desember 2019

P-ISSN 2622-8459 E-ISSN 2622-8467

http://ejournal.unima.ac.id/index.php/jemtec

\section{Conceptual Framework}

The reality on the ground shows that most students of the Japanese Language Education Study Program of Manado State University have not been accustomed enough to read and understand Japanese texts to get the information they need. This can be seen from their limited reading sources in Indonesian texts. This of course has a cause. The first reason that can be expected is that the mastery of Japanese vocabulary possessed by students is still low. The low mastery of Japanese vocabulary for students is also due to the lack of teaching that pays attention to the development of student vocabulary. The low mastery of Japanese vocabulary of students has an impact on students' ability to read Japanese text comprehension. There are still many students who do not understand the meaning of words in a reading. This can be seen when students work on practice questions, they tend to do other questions first than the questions about reading comprehension. In addition, there are still students who have not been able to find the main idea of each paragraph in a reading. Based on these facts it can be seen that the mastery of vocabulary is one of the factors that influence one's reading comprehension ability.

Based on the description above, the researcher wants to know the contribution of mastering Japanese vocabulary to the ability to read Japanese text comprehension by students of the Japanese Language Education Study Program of Manado State University. To find out the mastery of Japanese vocabulary and the ability to read Japanese text comprehension by research students conducted a test. The type of test used is a multiple-choice objective test model. The vocabulary test used is a passive-receptive vocabulary test. Indicator questions in this vocabulary test are to show according to the command, choose words that are in accordance with the meaning description, choose synonyms, and choose antonyms (Djiwandono, 2011). Whereas the reading comprehension test is only limited to reading basic level comprehension. The indicators used in the test of reading comprehension ability are understanding the meaning of words according to their use in the discourse, recognizing the organizational structure of the discourse and the interrelationships of its parts, recognizing the main points of thought expressed in the discourse, and being able to answer questions whose answers are explicitly contained in the discourse.

\section{Research Methods \\ Research Design}

The research approach used in this study is a quantitative approach using a causal correlation research. In this study, the variable to be examined is the mastery of vocabulary $(\mathrm{X})$ as the independent variable, while the ability to read comprehension (Y) as the dependent variable.

\section{Research Procedure}

The procedure of this study starts from the problems found by researchers that are clear. Problems found by researchers in the Japanese Language Education Study Program of Manado State University are students' vocabulary mastery is still low and students' reading comprehension skills are still lacking. The problem is then identified and constrained, and formulated in the form of sentence questions. To answer the problem formulation the researchers used various theories. After the 
researcher writes the theory, the next step is to determine the hypothesis. Hypothesis is a temporary answer to the formulation of a problem that will be empirically verified based on data from the field.

Before collecting data, researchers first determine the population and sample used. Data collection is done using tests. Researching is looking for accurate data. For this reason, researchers need to use research instruments. For instruments to be trusted, their validity and reliability must be tested. After the instrument has been tested for validity and reliability, it can be used to measure the variables that have been determined to be examined. The collected data is then analyzed to answer the problem formulation and the proposed hypothesis. Data analysis results are then presented and discussed, and later be concluded.

\section{Population and Samples}

The population in this study were all Japanese language students at the Faculty of Language and Art, Manado State University. The sample in this study was Japanese VI semester students of the Language and Arts Faculty of Manado State University who had studied Dokkai I courses and studied Dokkai II courses by 23 respondents.

\section{Data Collection Techniques}

Data collection techniques in this study used tests, which functioned as research instruments and were given to students who were sampled to determine the level of vocabulary mastery and reading comprehension.

The test instrument consists of 2 different test forms. The first test is a vocabulary test $(\mathrm{X})$, made in 2 types, namely:

a) Type $\mathrm{I}=$ decipher the meaning of 20 stand-alone words, and

b) Type II $=$ Deciphering 10 underlined words in sentences.

The second is the reading comprehension test $(\mathrm{Y})$ in which students read Japanese text, then answer 10 comprehension questions.

\section{Data Analysis Techniques}

Data analysis is an activity after data from all respondents or other data sources are collected (Sugiyono, 2015). Data analysis aims to arrange data in a meaningful way so that it can be easily understood. Analysis of the data used in this research is descriptive statistical analysis, analysis prerequisite test and hypothesis testing.

The analysis techniques used in this study are:

1) Correlation Analysis

According to Priyatno (2014) decision making about correlation analysis or the relationship between variable $\mathrm{X}$ to variable $\mathrm{Y}$ is seeing the correlation coefficient on the Summary Model R output column. If the number in column $\mathrm{R}$ approaches 1 , then the relationship between the independent variable and the dependent variable is tight and vice versa.

2) Coefficient of Determination

The coefficient of determination is the result of the square of the correlation coefficient which is changed in the form of percent. This aims to find out how much influence the variable $\mathrm{X}$ has on the variable $\mathrm{Y}$. To find out how much 
Journal of Educational Method and Technology Vol. 2 No. 3, Desember 2019

P-ISSN 2622-8459 E-ISSN 2622-8467

http://ejournal.unima.ac.id/index.php/jemtec

influence the variable $\mathrm{X}$ has on the variable $\mathrm{Y}$, it can be seen in the Model Square column R Square table. Then the number is converted into percent (Priyatno, 2014).

3) Simple Regression Equation

Sugiyono (2012) formulates a simple regression equation $\ddot{Y}=a+b X$

4) $T$ test

Decision making about the significance of the effect of variable $X$ on variable $\mathrm{Y}$ can be seen in the table (coefficients) column t-calc. According to Priyatno (2014) if t-calc $>$ t-crit and significance value $<0.05$, the null hypothesis is accepted. That is, there is a significant contribution between the variable $\mathrm{X}$ (the independent variable) against the $\mathrm{Y}$ variable (the dependent variable).

\section{Hypothesis}

The mastery of Japanese vocabulary contributes greatly to the understanding of Japanese reading texts in students of the Japanese Language Education Study Program, Faculty of Language and Art, Manado State University.

\section{Results and Discussion}

Results

The data described in this study includes data descriptions of all research variables as well as data of each variable which includes vocabulary mastery data (X) and reading comprehension skill data $(\mathrm{Y})$. Description of research data for all variables in this study are contained in the following table.

Table 1. Description of Research Results Data

\begin{tabular}{lcc}
\hline Statistic & $(\mathrm{X})$ & $(\mathrm{Y})$ \\
\hline $\mathrm{N}$ & 23 & 23 \\
Mean & 11.0420 & 10.8435 \\
Median & 11.0000 & 11.0000 \\
Mode & 12.00 & 10.00 \\
$\mathrm{SD}$ & 2.41208 & 3.55719 \\
\hline
\end{tabular}

a) Vocabulary Mastery Score (X)

Data on vocabulary mastery score $(\mathrm{X})$ obtained a range of scores between 5 to 18 , an average of 11.0420 , a standard deviation of 2.41208 . The median is 11.00 and the mode is located at a score of 12.00 . Grouping by category with a range of scores from 15 to 18 category is very good, a score of 11 to 14 categoriy is good, a score of 7 to 10 category is moderate, a score of 3 to 6 category is poor, and the category is very poor when the number of scores obtained $<3$. The score categories of the vocabulary mastery test results can be seen in Table 2 . 
Journal of Educational Method and Technology Vol. 2 No. 3, Desember 2019

P-ISSN 2622-8459 E-ISSN 2622-8467

http://ejournal.unima.ac.id/index.php/jemtec

Table 2. Frequency of Vocabulary Mastery Categories

\begin{tabular}{cccc}
\hline Interval & $\mathrm{F}$ & $\%$ & Kategori \\
\hline $15-18$ & 18 & 6,9 & Very good \\
$12-14$ & 94 & 35,7 & Good \\
$8-11$ & 135 & 51,8 & Moderate \\
$4-7$ & 15 & 5,7 & Poor \\
$<3$ & 0 & 0 & Very poor \\
\hline
\end{tabular}

In Table 2 it can be seen that $6.9 \%$ of respondents have very good mastery of words, $35.7 \%$ of respondents have good vocabulary mastery, $51.8 \%$ of respondents have moderate / moderate vocabulary, and 5.7\% of respondents have poor vocabulary mastery. Thus, most students have sufficient / moderate vocabulary empowerment. Categorization of vocabulary mastery scores can be described in Figure 3.

Figure 3. Vocabulary Mastery Categorization Diagram

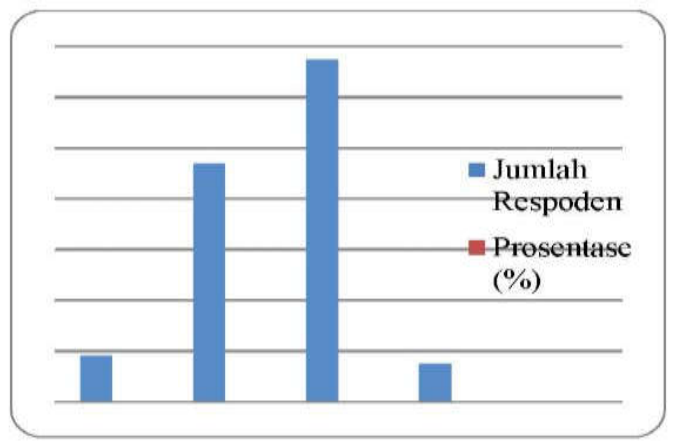

b) Understanding Reading Skills Score (Y)

Data on comprehension reading skills scores (Y) is shown in Table 4. Analysis results show a range of scores on reading comprehension skills between 1 to 19 , average (X) 10.8435, deviation (SD) at 3.5571, the median at 11.00, and the mode at the score of 10.00 . The range of scores of this variable consists of very good category, good category, moderate category, poor category and very poor category. Table 3 presents the results of the reading comprehension test scores.

Table 3. Frequency of Comprehension Reading Skills Categories

\begin{tabular}{crrc}
\hline Interval & $\mathrm{F}$ & $\%$ & Kategori \\
\hline $16-21$ & 28 & 10,6 & Very good \\
$11-15$ & 107 & 40,8 & Good \\
$6-10$ & 111 & 42,3 & Moderate \\
$1-5$ & 16 & 6,1 & Poor \\
$<1$ & 0 & 0 & Very poor \\
\hline
\end{tabular}

In Table 3 it is known that $10.6 \%$ of respondents have excellent reading comprehension skills, $40.8 \%$ of respondents have good reading comprehension skills, $42.3 \%$ of respondents have moderate reading comprehension skills, and 
Journal of Educational Method and Technology Vol. 2 No. 3, Desember 2019

P-ISSN 2622-8459 E-ISSN 2622-8467

http://ejournal.unima.ac.id/index.php/jemtec

reading skills understanding with the category of lacking $6.1 \%$ response $\neg$ den. Thus, students' reading skills fall into the medium category.

Figure 4. Frequency Diagram of Reading Comprehension Skills Category

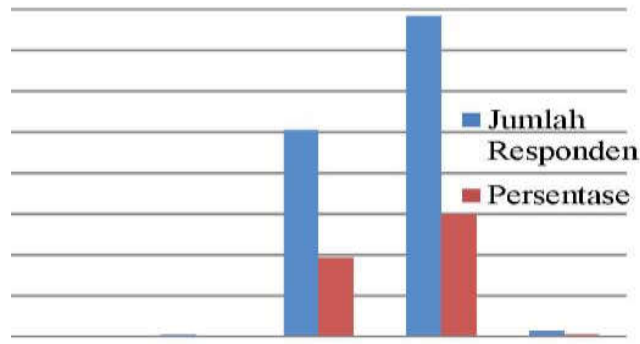

The calculation results for the hypothesis "mastery of vocabulary contributes positively to reading comprehension skills" found t-calc $=12,495$ with a significance of 0,000 , because $\mathrm{p}$ is greater than the significance of $0.05>$ 0,000 , then $\mathrm{H}_{0}$ is rejected, meaning there is a positive and significant relationship between mastery of vocabulary with reading comprehension skills. The results of a simple regression analysis are summarized in Table 4.

Table 4. $\mathrm{X}_{\mathrm{r}} \mathrm{Y}$ Correlation Test Results

\begin{tabular}{cccc}
\hline Model R R & Adj. R Square & t-calct & Sig. \\
\hline $\mathrm{X} .613^{\mathrm{a}} .375$ & .373 & 12.495 & $.000^{\mathrm{a}}$ \\
\hline
\end{tabular}

c) Relationship of Vocabulary Mastery and Reading Comprehension Skills From the results of calculations for testing the hypothesis "there is a relationship between vocabulary mastery and reading comprehension skills" found F-calc $=95.483$ with a significance of 0.00 . Because $\mathrm{p}$ is greater than its significance, which is $0.05>0.00$, then Ho is rejected, and Ha is accepted, meaning that there is a positive and significant relationship between mastery of vocabulary, accuracy of finding ideas together with reading comprehension skills. The results of the multiple regression analysis are summarized in Table 5.

Table 5. X and Y Regression Test Results

\begin{tabular}{cccccc}
\hline Model & $\mathrm{R}$ & $\mathrm{R}^{2}$ & Adj. R Square & F-calc & Sig. \\
\hline $\mathrm{XY}$ & $.651^{\mathrm{a}}$ & .424 & .420 & 95.483 & $.000^{\mathrm{a}}$ \\
\hline
\end{tabular}

To ascertain whether the independent variables contained in the equation individually affect the value of the dependent variable, a partial test or regression coefficient test is performed by testing the hypothesis on the regression coefficients of all independent variables. The partial test results are presented in Table 6.

Table 6. Partial Test Results of Xj.X2-Y and X2.XrY

\begin{tabular}{cccc}
\hline Model R R & Adj. R Square & t-calc & Sig. \\
\hline $\mathrm{X}_{2} .641^{\mathrm{a}} .411$ & .409 & 13.47 & $.000^{\mathrm{a}}$ \\
& & 1 & \\
\hline
\end{tabular}


Journal of Educational Method and Technology Vol. 2 No. 3, Desember 2019

P-ISSN 2622-8459 E-ISSN 2622-8467

http://ejournal.unima.ac.id/index.php/jemtec

From the test results it can be said that F-calc $>$ F-crit or F-calc is in the rejection area of $\mathrm{H}_{0}$ and accepting $\mathrm{H}_{\mathrm{a}}$, so it can be concluded that the variation in the change in the value of the dependent variable can be explained by the variation in the change in the value of all the independent variables. That is, all the independent variables $\left(\mathrm{X}_{1}\right.$ and $\left.\mathrm{X}_{2}\right)$ together or simultaneously can affect the dependent variable (Y).

\section{Discussion}

The results of the correlation analysis of vocabulary mastery with reading comprehension skills show the correlation coefficient of 0.613 and $p<0.05$, which means that mastery of vocabulary with understanding reading skills has a positive and significant relationship. The results of the regression analysis showed that the contribution of vocabulary mastery to the reading comprehension ability was 0.373 . the results of the partial correlation analysis produce a correlation coefficient of 0.151 , which means these results are smaller than the results of the correlation analysis individually between vocabulary mastery and reading comprehension skills. This means that mastering of vocabulary will have a greater influence on reading comprehension skills, if the relationship is uncontrolled by the accuracy of finding ideas. Vice versa, when compared with the correlation test conducted by control.

The results of this study prove that the better the vocabulary mastery, the higher the reading comprehension skills of students of the Japanese Language Study Program at the Faculty of Language and Art, Manado State University.

Based on the results of two-sided testing using a / 2 determination of t-crit with a significance level of $5 \%(a=0.05)$ and degree of freedom $(\mathrm{df})=260$, the critical value for this test is $\mathrm{t}(260 ; 0.05)=1.650735$. The ttest value for each regression coefficient based on the calculation results obtained t-test for b1 is 2.451 and t-test for b2 is 4.706. That is, the value of the regression coefficient of each regression equation is different from 0 (zero). Thus, based on the location of the ttest value of the regression coefficient on the normal curve, the t-test is located in the area of rejection of $\mathrm{H}_{0}$, so it can be said that $\mathrm{H}_{0}$ is rejected and $\mathrm{Ha}$ is accepted. It can be said, that the independent variable influences the dependent value, so it can be concluded that the independent variable $\mathrm{X}$ influences the dependent variable (Y).

To determine the effect of the independent variable on the dependent variable, a simultaneous test using the $\mathrm{F}$ distribution is performed by comparing the critical value of $\mathrm{F}$ with the value of F-calc or F-ratio contained in the Analysis of Variance (ANOVA) table. The hypothesis formulation for this test is as follows:

$\mathrm{H}_{0}$ : Variation changes in independent values cannot explain the variation in changes in the value of the dependent variable

$\mathrm{H}_{\mathrm{a}}$ : Variations in changes in the value of independent variables can explain variations in changes in the value of the dependent variable

The critical value in the $\mathrm{F}$ distribution with a significance level of $5 \%(\mathrm{a}=$ $0.05)$ and the degree of freedom $(\mathrm{df})$ is $\mathrm{F}(2 ; 259)=3.030$. F-calc value of the test results obtained F-ratio $=95.483$.

The results of the correlation analysis between vocabulary mastery and reading comprehension skills showed a correlation coefficient value of 0.651 and $p$ $<0.05$, which means that vocabulary mastery and accuracy of finding ideas with reading comprehension skills had a positive and significant relationship. The results 
of the regression analysis showed that the contribution of mastery of vocabulary to reading comprehension skills was 0.420 .

Thus, it can be concluded that the mastery of vocabulary and reading skills of students' understanding of Japanese Language Study Program at the Faculty of Language and Art of Manado State University has been proven to have a positive and significant relationship. Based on the calculation of the coefficient of determination $\left(\mathrm{R}^{2}\right)$ the results obtained are the value of $\mathrm{R}^{2}=0.424$ and adjusted $\mathrm{R}$ square of 0.420 . This result can be interpreted that the effect of variable $\mathrm{X}$ (independent) on the $\mathrm{Y}$ variable (dependent) is $42 \%$, while the remaining $58 \%$ is influenced by other variables. For this reason, it can be concluded that there are still variables other than the mastery of vocabulary and the accuracy of finding ideas that influence the reading comprehension skills.

\section{Conclusions And Suggestions Conclusions}

There is a positive and significant relationship between vocabulary mastery and reading comprehension skills of Japanese Language Education Study Program of Manado State University with a correlation coefficient of $0.613, \mathrm{R}^{2}$ of 0.375 , adjusted $\mathrm{R}$ of 0.373 with $\mathrm{p}<0.05$, and correlation coefficient partially 0,151 . Vocabulary mastery is predicted to have an influence on reading comprehension skills by $37.3 \%$, if the relationship is without control of the accuracy of finding ideas, while the relationship between vocabulary empowerment and reading comprehension skills is controlled by the accuracy variable to determine the idea of correlation magnitude is .151.

There is a positive and significant relationship between the accuracy of finding ideas with reading comprehension skills of Japanese Language Education Study of Manado State University with a correlation coefficient of $0.641, \mathrm{R}^{2}$ of 0.411 , adjusted $\mathrm{R}$ of 0.409 or $40.9 \%$ with $\mathrm{p}<0,05$, and the partial correlation coefficient of 0.281 . The accuracy of finding ideas is predicted to have an influence on reading comprehension skills by $40.9 \%$, if the relationship is without the control of vocabulary mastery, while the correlation of accuracy of finding ideas with reading comprehension skills is controlled by vocabulary mastery variables the magnitude of correlation is 0.281 .

There is a positive and significant correlation between vocabulary mastery and accuracy of finding ideas together with reading comprehension skills with $\mathrm{R}$ of $0.651, R^{2}$ of 0.424 , and adjusted $R$ square of 0.420 with a significance of $p<0.05$. The contribution of vocabulary mastery and accuracy of finding ideas to reading comprehension skills is $42 \%$, while the remaining $58 \%$ is influenced by other variables, in addition to mastery of vocabulary and accuracy of finding ideas. Therefore, research is needed other than these variables which may be related to reading comprehension skills. From the hypothesis proposed that the mastery of vocabulary and accuracy of finding ideas with reading comprehension skills of students of the Japanese Language Education Study Program of Manado State University proved to have a positive and significant influence. 
Journal of Educational Method and Technology Vol. 2 No. 3, Desember 2019

P-ISSN 2622-8459 E-ISSN 2622-8467

http://ejournal.unima.ac.id/index.php/jemtec

\section{Suggestion}

To improve reading skill, it needs to be fully supported by teachers, especially teachers in the field of Indonesian language studies. This needs to be done so that students have high comprehension reading skills so they can support the ability to understand written information. To improve students' vocabulary mastery needs to be done by the teacher through learning activities in schools both through Indonesian and other subjects. To improve students' ability to find ideas correctly can be done through activities to train students to find the main ideas and explanatory ideas in a paragraph/text/discourse. The reader can develop this research further by discussing other concepts such as mastery of language structure, speed of reading.

\section{REFERENCES}

Balai Pustaka. (1990). Kamus Besar Bahasa Indonesia [Great Indonesian Dictionary].

Chaer, A. (2011). Tata Bahasa praktis Bahasa Indonesia [Practical Indonesian grammar]. Jakarta: Rineka. Cipta

Dalman. (2014). Keterampilan Membaca [Reading skill]. Jakarta: Rajawali Press

Djiwandono, S. (2011). Tes Bahasa Pegangan Bagi Pengajar Bahasa [The handbook of language testing for language teacher]. Malang: PT. Indeks.

Keraf, G. (2007). Argumentasi dan Narasi [Argumentation and narration]. Jakarta: PT Gramedia Pustaka Utama.

Nurgiyantoro, B. (2014). Stilistika [Stylistics]. Yogyakarta: Gadjah Mada University Press.

Rahim, F. (2008). Pengajaran Membaca di Sekolah Dasar [Teaching reading in elementary school]. Jakarta: Bumi Aksara.

Roe, B. \& Burns, P. C. (2010). Informal Reading Inventory: Preprimer to Twelfth Grade (What's New in Education). Boston: Cengage Learning

Rooijakkers, A. (1991). Mengajar dengan Sukses [Teach succesfully]. Jakarta: Gramedia

Somadayo, S. (2011). Strategi dan Teknik Pembelajaran Membaca [Strategy and technique of reading learning]. Yogyakarta: Graha Ilmu

Tarigan, H. G. (2008). Membaca sebagai Suatu Ketrampilan Berbahasa [Reading as a language skill]. Bandung: Angkasa.

Tarigan, H. G. (2015). Pengajaran Kosakata [Vocabulary teaching]. Bandung: Angkasa

Widyamartaya. (2000). Seni Membaca untuk Studi [The art of reading for study]. Yogyakarta: Kanisius.

Wiryodijoyo, S. (1989). Membaca: Strategi, Pengantar dan Tekniknya [Reading: strategy, introduction and techniques]. Jakarta: Departemen Pendidikan dan Kebudayaan. 